\title{
Enhanced epidemic intelligence using a web-based screening system during the 2010 FIFA World Cup in South Africa
}

\author{
J Mantero, E Szegedi (edit.szegedi@ecdc.europa.eu)1, L Payne Hallström², A Lenglet ${ }^{2}$ E Depoortere ${ }^{2}$, B Kaic ${ }^{3}$, L Blumberg ${ }^{4}$, J P \\ Linges, D Coulombier $^{2}$ \\ 1. Epidemic Intelligence group, European Centre for Disease Prevention and Control (ECDC), Stockholm, Sweden \\ 2. Surveillance and Response Support Unit, European Centre for Disease Prevention and Control (ECDC), Stockholm, Sweden \\ 3. Croatian National Institute of Public Health, Zagreb, Croatia (deployed at ECDC during the 2010 FIFA World Cup) \\ 4. Division of Public Health Surveillance and Response, National Institute for Communicable Diseases (NICD), Johannesburg, \\ South Africa \\ 5. Global Security \& Crisis Management Unit, Joint Research Centre of the European Commission, Ispra, Italy
}

Citation style for this article:

Mantero J, Szegedi E, Payne Hallström L, Lenglet A, Depoortere E, Kaic B, Blumberg L, Linge JP, Coulombier D. Enhanced epidemic intelligence using a web-based screening system during the 2010 FIFA World Cup in South Africa. Euro Surveill. 2014;19(18):pii=20796. Available online: http://www.eurosurveillance.org/

ViewArticle.aspx?Articleld $=20796$

Article submitted on 13 March 2013 / published on 08 May 2014

The 2010 FIFA World Cup took place in South Africa between 11 June and 11 July 2010. The European Centre for Disease Prevention and Control (ECDC), in collaboration with the hosting authorities, carried out enhanced epidemic intelligence activities from 7 June to 16 July 2010 for timely detection and monitoring of signals of public health events with a potential to pose a risk to participants and visitors. We adapted ECDC's routine epidemic intelligence process to targeted event-based surveillance of official and unofficial online information sources. A set of three specifically adapted alerts in the web-based screening system MedISys were set up: potential public health events in South Africa, those occurring in the participating countries and those in the rest of the world. Results were shared with national and international public health partners through daily bulletins. According to pre-established ECDC criteria for the World Cup, 21 events of potential public health relevance were identified at local and international level. Although none of the events detected were evaluated as posing a serious risk for the World Cup, we consider that the investment in targeted event-based surveillance activities during the tournament was relevant as it facilitated real-time detection and assessment of potential threats. An additional benefit was early communication of relevant information to public health partners.

\section{Introduction}

The 2010 FIFA World Cup

The 2010 Fédération Internationale de Football Association (FIFA) World Cup took place in South Africa between 11 June and 11 July 2010 [1]. It was one of the largest mass gathering events (MGs) ever organised on the African continent, with the participation of 32 national football teams (Figure), including 11 teams from European Union (EU)/ European Economic Area (EEA) countries: Denmark, England, France, Germany, Greece, Italy, the Netherlands, Portugal, Slovakia,
Slovenia, and Spain. More than 300,000 foreign football fans visited South Africa to attend the event (around 72,000 (24\%) from Europe), in addition to the 10 million tourists who visit South Africa each year [2].

Mass gathering and risk of infectious diseases The World Health Organization (WHO) defines a mass gathering event (MG) as an event attended by more than 1,000 individuals in a specific location for a specific purpose and for a defined period of time [3]. The term 'mass gathering' generally refers to major international public events, such as sporting events or religious gatherings as well as unplanned events with large number of attendees, which can put a strain on the planning and response resources of the hosting community.

Large numbers of visitors in the same area at the same time may increase the risk of communicable disease outbreaks. Several factors contribute to this theoretical increase, such as increased person-to-person transmission of pathogens due to the localised high population density, risk of importation of nonDendemic diseases, exportation of endemic diseases, challenges in contact tracing due to visitor mobility and temporary structures such as mass catering and accommodation for visitors. Non-communicable health risks are also relevant, including heat stroke, crowd injury and drug- and alcohol-related conditions. Additionally, as MGs are often high-profile events, other risks such as security or bioterrorism threats also need to be taken into consideration. The increased risk of public health events during MGs poses special challenges for the hosting authorities in terms of public health preparedness and communication. Media attention might lead to the need for timely communication to the general public and to participants' home communities upon their return. 


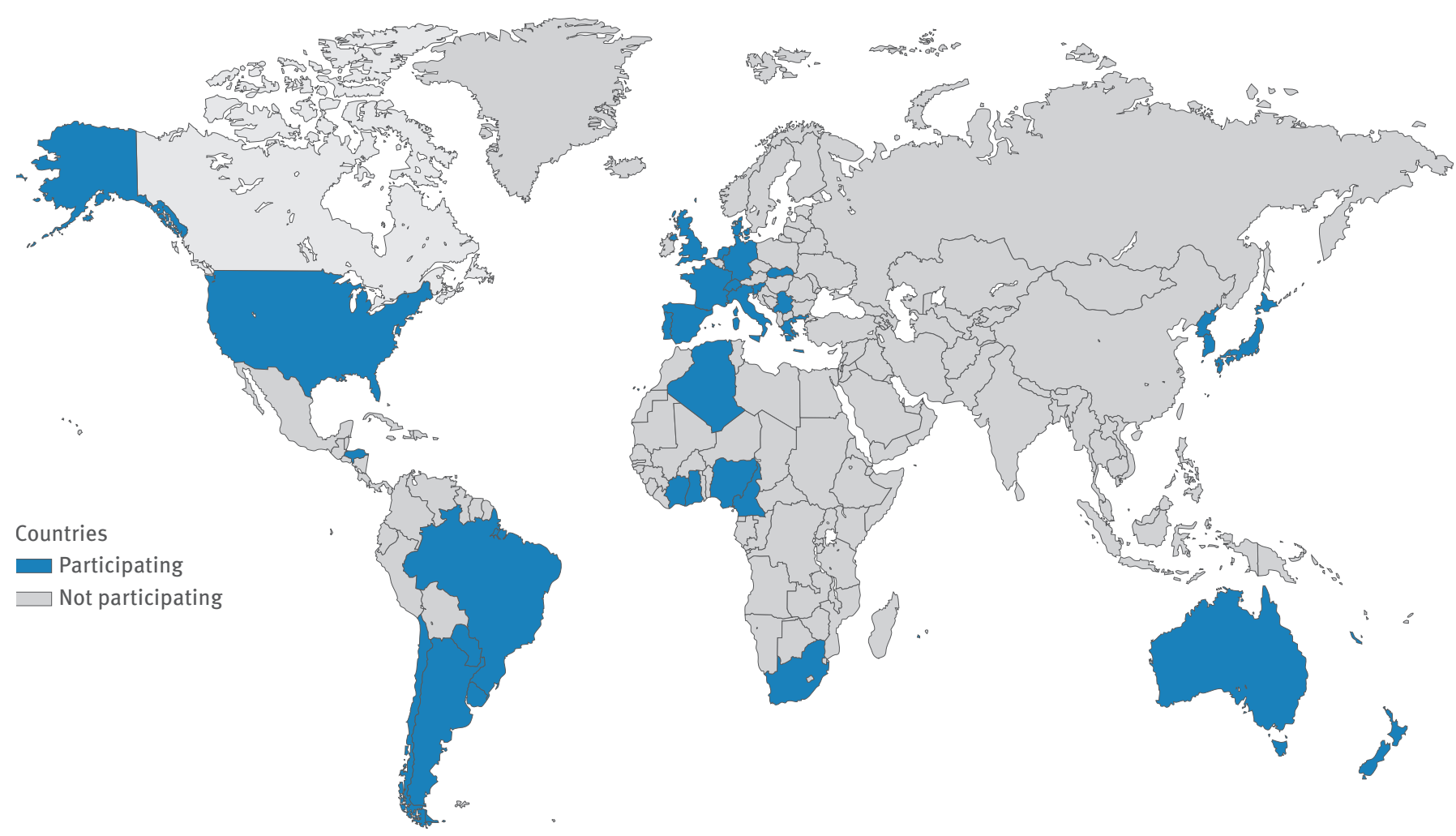

FIFA: Fédération Internationale de Football Association.

ECDC epidemic intelligence activities

ECDC refers to epidemic intelligence (EI) as the systematic process of collection, validation and analysis of information about potential public health events from a virtually unlimited amount of sources $[4,5]$. Its purpose is to speed up the detection of possible public health events in order to allow the implementation of timely response actions after an adequate risk assessment. This includes real-time monitoring of the risk these events might pose. The El process uses official data provided by national health authorities through indicator-based surveillance as well as the monitoring of additional information through event-based surveillance.

ECDC activities during a MG focus mostly on the eventbased surveillance component, in particular on the processing of web-based information. To do so, we use advanced technologies, defined as event-based surveillance web systems, which are able to gather, filter and classify public health information online. MediSys is among the EBS web systems most frequently used for El purposes at ECDC because of its extreme flexibility and possible customisation [6]. The system, developed in 2006 by the European Commission's Joint Research Centre, is capable of screening selected publicly available web sources, including online media and government websites, using multilingual categorisation based on alert definitions using keywords in over 40 languages $[7,8]$. Online items of potential public health interest are automatically classified in specific disease categories if they satisfy the corresponding alert definitions, which may contain Boolean operators, proximity operators, wildcard characters and the use of cumulative positive or negative weights with an adjustable threshold. All news items are classified and geo-located in a user interface accessible on the web.

\section{ECDC epidemic intelligence activities during the 2010 World Cup}

In line with ECDC's Founding Regulation, which states that the agency's role is to 'identify, assess and communicate current and emerging threats to human health from communicable diseases in order to strengthen Europe's defences against infectious diseases' [9], we undertook to inform EU national health authorities and the European Commission in real time about possible public health risks for EU citizens during the 2010 World Cup.

The aim of this article is to present the adapted ECDC El strategy developed six months before and put in place specifically for 2010 World Cup, to present the web-technology used for performing event-based 
List of MedISys filters created for the 2010 FIFA World Cup, South Africa, 7 June-16 July 2010

\begin{tabular}{|l|l|l|}
\hline MedISys filters & Description & Purpose \\
\hline Filter 1 & $\begin{array}{l}\text { Selected communicable diseases } \\
\text { occurring in South Africa }\end{array}$ & $\begin{array}{l}\text { Identify web information about selected communicable diseases and } \\
\text { syndromes considered to be more likely to occur in South Africa }\end{array}$ \\
\hline Filter 2 & Other public health events in South Africa & $\begin{array}{l}\text { Identify web information about non-infectious disease events of possible } \\
\text { public health interest at the game venues (e.g. crowd injuries, heat stroke } \\
\text { and security issues) }\end{array}$ \\
\hline Filter 3 & $\begin{array}{l}\text { Selected communicable diseases to } \\
\text { South Africa from participating countries }\end{array}$ & $\begin{array}{l}\text { Identify web information about selected communicable diseases considered } \\
\text { to be at risk for importation to the host country from participating countries } \\
\text { (excluding South Africa) }\end{array}$ \\
\hline Filter 4 & $\begin{array}{l}\text { Selected communicable diseases in } \\
\text { countries neighbouring South Africa }\end{array}$ & $\begin{array}{l}\text { Identify web information about selected communicable diseases considered } \\
\text { to be at risk for importation to South Africa from bordering countries }{ }^{\text {b }}\end{array}$ \\
\hline
\end{tabular}

FIFA: Fédération Internationale de Football Association.

MedISys, developed at the Joint Research Centre of the European Commission, is an Internet-based system that continuously monitors specialist medical sites and news sites to rapidly identify potential threats to public health.

a Algeria, Argentina, Australia, Brazil, Cameroon, Chile, Côte d'Ivoire, Denmark, England, France, Germany, Ghana, Greece, Honduras, Italy, Japan, Mexico, Netherlands, New Zealand, Nigeria, North Korea, Paraguay, Portugal, Serbia, Slovakia, Slovenia, South Korea, Spain, Switzerland, Uruguay and the United States.

b Namibia, Botswana, Mozambique, Swaziland, Zimbabwe and Lesotho.

surveillance for this MG and report findings in terms of identified public health events communicated in real time with public health partners.

\section{Methods}

We adapted ECDC's routine El process [4] for a defined period of time starting two weeks before the beginning of the 2010 World Cup (7 June 2010) and ending one week after the closing ceremony (16 July 2010). The objective was to allow early detection and monitoring of signals of public health events with a potential to pose a risk to participants and visitors.

Routine El activities were enhanced by expanding the information sources, using a targeted and systematic screening approach using tailored tools (MediSys), determining validation sources, establishing a daily analysis and communication process with regular and specific public health partners and developing specific reports. Processes were then re-integrated into the structure of routine El activities at ECDC with no additional allocated budget. We benefited from an additional full-time seconded expert (B. Kaic) for weekday additional screening and daily report production.

\section{Screening of public health information} potentially relevant to the 2010 World Cup through MedISys

Following a review of the existing list of online media sources screened by MedISys, we added, in collaboration with European Commission's Joint Research Centre, relevant publicly available media web sources and websites of health authorities of the host country, its neighbours and those of the participating countries.
New multilingual alert definitions were set up, which included languages of participating countries not yet covered by the system, geo-terms specific to South Africa in order to locate the information identified (names of regions, provinces, cities, neighbourhoods and game venues) as well as a limited set of communicable diseases and symptoms. The list of diseases and symptoms was based on an ECDC internal assessment of risk of infectious diseases considering official information from the National Institute for Communicable Diseases (NICD) in Johannesburg, public health reports and travel advice issued by national and international organisations worldwide before the event [10-13]. The list of diseases comprised the following: tick bite fever, Crimean Congo haemorrhagic fever, chikungunya, cholera, dengue, food-borne disease, hand, foot and mouth disease, human immunodeficiency virus (HIV) infection, influenza, legionellosis, malaria, measles, meningococcal meningitis, sexually transmitted infections, poliomyelitis, rabies, Rift Valley fever, respiratory syncytial virus infection, rubella, tuberculosis and yellow fever.

Customised pages were then created in MedISys dedicated to the 2010 World Cup, where selected disease alerts were combined with alerts for selected countries in order to create display filters for online information of potential interest (Table 1).

\section{Filtering screened information for potential public health events}

- We established criteria to evaluate the web information selected by MedISys regarding public health relevance for the tournament. These were: 
Detected or monitored public health events during the 2010 FIFA World Cup, South Africa, 7 June-16 July 2010 in the host country and their relevance for the event

\begin{tabular}{|c|c|c|c|}
\hline $\begin{array}{l}\text { Public health } \\
\text { event }\end{array}$ & Source & Description & $\begin{array}{l}\text { ECDC actions and assessment of relevance for the } \\
\text { event }\end{array}$ \\
\hline Influenza & $\begin{array}{l}\text { NICD }[10-12,29], \text { WHO [31], } \\
\text { media reports (MedISys } \\
\text { alert) }\end{array}$ & $\begin{array}{l}\text { Low activity with initially influenza } \\
\text { B virus circulation, later moderate } \\
\text { with the addition of } A\left(\mathrm{H}_{3} \mathrm{~N}_{2}\right) \text { and } \\
\text { pandemic } A\left(\mathrm{H}_{1} \mathrm{~N}_{1}\right) \text { strains. }\end{array}$ & $\begin{array}{l}\text { Several cases among participants/visitors reported } \\
\text { by media but overall no relevant spread to the } \\
\text { community for the } 2010 \text { World Cup. }\end{array}$ \\
\hline Rift Valley fever & $\begin{array}{l}\text { NICD [10-12], media } \\
\text { reports (MedISys alert) }\end{array}$ & $\begin{array}{l}\text { Ongoing nationwide outbreak, with } \\
\text { first cases reported in February } 2010 \\
\text { ( } 228 \text { confirmed cases including } 26 \\
\text { deaths). }\end{array}$ & $\begin{array}{l}\text { All confirmed cases had direct contact with } \\
\text { infected animal tissue. No cases among visitors/ } \\
\text { participants and no relevance for the } 2010 \text { World } \\
\text { Cup. }\end{array}$ \\
\hline $\begin{array}{l}\text { Meningococcal } \\
\text { meningitis }\end{array}$ & $\begin{array}{l}\text { NICD }[10-12,29], \text { media } \\
\text { reports (MedISys alert) }\end{array}$ & $\begin{array}{l}105 \text { confirmed cases ( } \mathrm{n}=85 \text { due to } \\
\text { Neisseria meningitidis } \mathrm{B} / \mathrm{W}_{135} \text { ). }\end{array}$ & $\begin{array}{l}\text { No direct risk for visitors/participants and no cases } \\
\text { reported among either group. It had no relevance } \\
\text { for the } 2010 \text { World Cup. }\end{array}$ \\
\hline Measles & $\begin{array}{l}\text { NICD [10-12], media } \\
\text { reports (MedISys alert) }\end{array}$ & $\begin{array}{l}\text { An ongoing measles outbreak (B3 } \\
\text { genotype) since } 2009 \text {. A mass } \\
\text { vaccination campaign took place } \\
\text { before the event. }\end{array}$ & $\begin{array}{l}\text { No cases reported among visitors/participants } \\
\text { during the World Cup but cases potentially linked } \\
\text { to the event afterwards in several countries. }\end{array}$ \\
\hline Malaria & $\begin{array}{l}\text { Media reports [22], } \\
\text { (MedISys alert) }\end{array}$ & $\begin{array}{l}\text { Two fatalities reported by media in a } \\
\text { South Korean dance group were not } \\
\text { considered to be linked to infection in } \\
\text { South Africa. }\end{array}$ & $\begin{array}{l}\text { Risk for malaria in visitors/participants was } \\
\text { considered low. }\end{array}$ \\
\hline Canine rabies & $\begin{array}{l}\text { NICD }[23,24], \text { media } \\
\text { reports (MedISys alert) }\end{array}$ & $\begin{array}{l}\text { Ten canine cases were reported } \\
\text { in domestic dogs in a suburb of } \\
\text { Johannesburg. }\end{array}$ & $\begin{array}{l}\text { No human exposure occurred during the } \\
\text { surveillance period; however, a local case with } \\
\text { symptom onset at end of August } 2010 \text { was } \\
\text { confirmed later by the NICD. It had no relevance for } \\
\text { the } 2010 \text { World Cup. }\end{array}$ \\
\hline $\begin{array}{l}\text { Food-borne } \\
\text { illness }\end{array}$ & $\begin{array}{l}\text { Media reports }[26,27] \\
\text { (MediSys alert) }\end{array}$ & $\begin{array}{l}\text { Two limited food-borne illness } \\
\text { outbreaks at game venues. }\end{array}$ & $\begin{array}{l}\text { Outbreaks confirmed by the NICD and assessed } \\
\text { as local events with limited or no risk for visitors/ } \\
\text { participants. It was of no relevance for the } 2010 \\
\text { World Cup. }\end{array}$ \\
\hline
\end{tabular}

ECDC: European Centre for Disease Prevention and Control; FIFA: Fédération Internationale de Football Association; NCID: National Institute for Communicable Diseases, Johannesburg, South Africa; WHO: World Health Organization.

The enhanced surveillance period was from 7 June to 16 July 2010.

MedISys, developed at the Joint Research Centre of the European Commission, is an Internet-based system that continuously monitors specialist medical sites and news sites to rapidly identify potential threats to public health.

- suspected or confirmed cases of communicable diseases of public health relevance for the 2010 World Cup;

- suspected or confirmed cases of communicable diseases of public health relevance occurring in South Africa (risk to EU visitors/participants, risk of importation to the EU);

- incidents in South Africa related to international security, such as possible intentional release of biological agents, nuclear and chemical events;

- suspected or confirmed cases of communicable diseases of public health relevance for the World Cup occurring in countries with national teams participating in the World Cup and in countries bordering South Africa (risk of exportation to South Africa and local spread);

- incidents occurring in South Africa drawing media attention in the EU, such as outbreaks in tourist areas, crowd injuries, rumours about possible spread of communicable diseases among visitors or participants.

\section{Validation and analysis of potential public health events} Information on public health events detected in EU/ EEA countries was validated through routine channels with EU Member States, while those detected outside the EU/EEA (excluding South Africa) were validated through the WHO Regional Office for Europe and the ECDC El international network.

Public health events identified in South Africa were validated and assessed through information available from the NICD. The NICD undertook daily laboratory surveillance at national level and was a core member of the Public Health Cluster at the National Operations Centre, which was responsible for the risk assessment of each incident/event. The NICD also posted regular official epidemiological updates on the web, providing real-time public information on current outbreaks or diseases of interest in the country, such as measles, influenza and Rift Valley fever. 
We analysed all validated events at ECDC on a daily basis during regular El meetings with the participation of ECDC disease-specific experts, taking into consideration the information provided by South Africa and WHO Regional Office for Europe.

\section{Communicating the epidemic intelligence findings}

During the entire period of the enhanced surveillance, ECDC produced a daily bulletin summarising the results of the daily El activities (signal source, public health topic and summary, validation status, ECDC assessment of relevance). This bulletin was shared daily with the NICD, WHO Regional Office for Europe and interested EU Member States.

\section{Results}

Targeted ECDC El activities during the 2010 World Cup were undertaken for six weeks: 21 incidents of potential public health relevance according to ECDC criteria were detected or monitored. Seven of them occurred in South Africa.

\section{Potential public health incidents in South Africa}

A short summary of all potential public health threats in South Africa identified or monitored by ECDC during the enhanced surveillance period is shown in Table 2.

\section{Influenza}

The football tournament occurred during the expected influenza season in South Africa. Thus, ECDC started to monitor the influenza activity in South Africa before the event, consulting the NICD and WHO reports supplemented with online media reports, which were verified when necessary. Overall, the influenza activity was low to moderate during the tournament. Initially, only influenza $B$ virus was circulating; both $A\left(\mathrm{H}_{3} \mathrm{~N}_{2}\right)$ and $A\left(\mathrm{H}_{1} \mathrm{~N}_{1}\right)$ pdmog virus strains were detected later during the surveillance period [10-12]. Despite some reported cases of influenza among participants and officials, no spread to other participants or officials was identified. We considered the risk of contracting influenza for EU visitors and/or participants as low during the enhanced surveillance period.

\section{Rift Valley fever}

There was an ongoing large nationwide outbreak of Rift Valley fever during 2010 in South Africa and there had been some concerns regarding the risk for EU tourists contracting the disease following reports of a German visitor who was thought to have been infected in the country before the start of the event [14]. ECDC monitored Rift Valley fever during the enhanced surveillance period using information regularly provided by the NICD and through media reports. However, all confirmed cases were reported in non-tourist areas and in individuals who had had direct contact with infected animal tissue (farm workers, as a result of occupational exposure). The German case was later discarded by the national authorities following a subsequent diagnosis of rickettsial infection [15].

Meningococcal disease

Meningococcal disease in South Africa occurs normally in sporadic outbreaks, mainly during droughts, dry and dusty conditions or winter seasons, with a predominance of Neisseria meningitidis serogroup B and W135. Media attention on this had been particularly intense shortly before the 2010 World Cup following the death due to meningococcal meningitis of a well-known local opera singer who was scheduled to perform during the opening ceremony [16]. Because of the risk of infection for unvaccinated visitors, vaccination against meningococcal disease was recommended for visitors and participants before the event by the NICD [13]. Updated information about new cases of meningitis was regularly published online by the NICD during the enhanced surveillance period and was included in the daily ECDC bulletin. No cases were reported among visitors and participants.

\section{Measles}

There was an ongoing measles outbreak in South Africa during the 2010 World Cup: it began in the second half of 2009, with more than 15,000 cases reported by July 2010 [10-12]. ECDC closely followed the situation in the country through regular updates provided by the NICD, taking into consideration the likelihood of unvaccinated visitors contracting the virus and the risk of exportation of cases to non-endemic countries. The NICD informed ECDC that there had been a mass vaccination campaign before the event. Measles updates were included in the daily ECDC bulletins in order to draw the attention of EU national health authorities to the importance of vaccination for EU citizens visiting South Africa. ECDC also informed the general public about the need for vaccination through the ECDC website, both before and during the MG. Sporadic cases were also reported in unvaccinated Australian visitors returning from the event $[17,18]$. In September 2010, health authorities in Argentina, a country that has been measles free since 2000 , issued public health alerts after confirmed local transmission of measles virus suspected to be linked to measles cases in citizens who visited South Africa during the 2010 World Cup [19]. Other measlesfree countries in South America including Brazil and Uruguay also issued public health alerts for measles in the following months $[20,21]$.

\section{Malaria}

The risk of contracting malaria in South Africa was considered very low by the NICD and ECDC for participants and visitors, partly because the venues for the games were outside risk areas with high transmission and partly because the games took place during the lowtransmission period. Two fatalities due to malaria were reported in South Korean members of an international dance group visiting South Africa before the World Cup [22]. This report led to increased media attention on the risk of malaria in South Africa. The NICD confirmed the 
Detected or monitored public health events during the 2010 FIFA World Cup, South Africa, 7 June-16 July 2010 in participating countries and their relevance for the event

\begin{tabular}{|c|c|c|c|}
\hline Event, country & Source & Description & $\begin{array}{l}\text { ECDC actions and assessment } \\
\text { of relevance for the event }\end{array}$ \\
\hline $\begin{array}{l}\text { Hepatitis A, the } \\
\text { Netherlands }\end{array}$ & $\begin{array}{l}\text { Media reports (MedISys } \\
\text { alert) }\end{array}$ & $\begin{array}{l}\text { An increase in the number of cases } \\
\text { was reported in Zeeland province }\end{array}$ & $\begin{array}{l}\text { Validation through the national health authorities: } \\
\text { two separate clusters confirmed among travellers } \\
\text { abroad (not South Africa). No relevance for the } \\
2010 \text { World Cup. }\end{array}$ \\
\hline $\begin{array}{l}\text { Legionnaires' } \\
\text { disease, Spain }\end{array}$ & $\begin{array}{l}\text { Media reports (MedISys } \\
\text { alert) }\end{array}$ & Outbreak reported in Alcoy & $\begin{array}{l}\text { Validation through the national health authorities: } \\
\text { confirmation of a local outbreak with no history of } \\
\text { travelling. No relevance for the } 2010 \text { World Cup. }\end{array}$ \\
\hline Measles, Italy & $\begin{array}{l}\text { Media reports (MedISys } \\
\text { alert) }\end{array}$ & $\begin{array}{l}\text { Increased number of cases reported } \\
\text { in Sicily }\end{array}$ & $\begin{array}{l}\text { Validation through web-based information. At least } \\
\text { three outbreaks identified, control measures taken } \\
\text { (no travel history). No relevance for the } 2010 \text { World } \\
\text { Cup. }\end{array}$ \\
\hline Measles, Greece & Media reports [32] & $\begin{array}{l}\text { A relevant increase in the number of } \\
\text { cases was reported in Greece }\end{array}$ & $\begin{array}{l}\text { Validation through national health authorities. } \\
\text { Possible relation with cases in Bulgaria. No } \\
\text { relevance for the } 2010 \text { World Cup. }\end{array}$ \\
\hline Dengue, Italy & $\begin{array}{l}\text { Media reports (MedISys } \\
\text { alert), [33] }\end{array}$ & $\begin{array}{l}\text { An imported case was reported in an } \\
\text { area where the competent vector is } \\
\text { present }\end{array}$ & $\begin{array}{l}\text { Validation through local health authorities' } \\
\text { website; the case travelled to South- East Asia. No } \\
\text { relevance for the } 2010 \text { World Cup. }\end{array}$ \\
\hline $\begin{array}{l}\text { Anthrax, United } \\
\text { Kingdom and } \\
\text { Germany, in } \\
\text { injecting drug } \\
\text { users }\end{array}$ & $\begin{array}{l}\text { Official reports [34], } \\
\text { (MedISys alert) }\end{array}$ & $\begin{array}{l}\text { Cases reported since December } 2009 \text {. } \\
\text { By the end of the World Cup, } 47 \text { cases } \\
\text { had been identified, with } 13 \text { fatalities }\end{array}$ & $\begin{array}{l}\text { Any update during the enhanced surveillance } \\
\text { period for } 2010 \text { FIFA was validated through local } \\
\text { authorities and shared with ECDC disease experts } \\
\text { for analysis. No relevance for the } 2010 \text { World Cup. }\end{array}$ \\
\hline
\end{tabular}

ECDC: European Centre for Disease Prevention and Control; FIFA: Fédération Internationale de Football Association.

The enhanced surveillance period was from 7 June to 16 July 2010.

MedISys, developed at the Joint Research Centre of the European Commission, is an Internet-based system that continuously monitors specialist medical sites and news sites to rapidly identify potential threats to public health.

low level of risk as initially assessed and indicated that the two cases were thought not to have been infected in South Africa.

\section{Canine rabies}

Ten cases of canine rabies were reported in Metropolitan Johannesburg by the NICD [23]. However, the authorities considered the occurrence of rabies to be of limited public health concern, with post-exposure prophylaxis confirmed as being readily available [1012,24]. Nonetheless, ECDC included the information about the canine cases in the daily ECDC bulletins to raise awareness among national health authorities about the potential risk of exposure for EU visitors. In September 2010, the NICD confirmed a human local case of rabies in Johannesburg in a child with onset of symptoms in August, which was linked to the animal cases reported during the previous weeks in the same city [25].

\section{Food-borne illness}

The NICD issued advice for travellers regarding food safety and recommending caution when purchasing food from street vendors or other food outlets. There were two isolated outbreaks of food-borne illness occurring at game venues during the enhanced surveillance period without serious effects, reported first by the media $[26,27]$ and later confirmed by NICD: one with Bacillus cereus as the causative agent, the other with unknown aetiology [11-12].

\section{Potential public health incidents in participating countries during the 2010 World Cup}

We considered six events as being of potential public health risk at EU level during the enhanced surveillance period (hepatitis A, Legionnaires' disease, measles (in two countries), dengue and anthrax) but none were deemed relevant for the World Cup (see short description in Table 3).

\section{Potential public health incidents in non- participating countries during the 2010 World Cup}

ECDC detected or monitored six public health events of potential EU concern in non-participating countries, which were not deemed relevant the event (see short description in Table 4).

\section{Discussion}

ECDC seeks to protect EU/EEA citizens from infectious diseases through early detection, monitoring and assessment of public health signals in the EU/ EEA and worldwide. In the case of large MGs attracting 
Public health events detected or monitored during the 2010 FIFA World Cup, 7 June-16 July 2010, in non-participating countries and their relevance for the event

\begin{tabular}{|c|c|c|c|}
\hline Event, country & Source & Description & $\begin{array}{l}\text { ECDC actions and assessment of relevance for the } \\
\text { event }\end{array}$ \\
\hline $\begin{array}{l}\text { Measles, } \\
\text { Bulgaria }\end{array}$ & $\begin{array}{l}\text { National health authorities } \\
\text { [35], media reports } \\
\text { (MediSys alert) }\end{array}$ & $\begin{array}{l}\text { This event was already being } \\
\text { monitored by ECDC before the } 2010 \\
\text { World Cup. From January } 2010 \text { to } \\
\text { the end of the event, the cumulative } \\
\text { number of cases was of } 21,180 \text { (with } \\
20 \text { deaths). }\end{array}$ & $\begin{array}{l}\text { The outbreak started in } 2009 \text { and was monitored } \\
\text { as part of ECDC routine activities. No relevance for } \\
\text { the } 2010 \text { World Cup. }\end{array}$ \\
\hline $\begin{array}{l}\text { Poliomyelitis, } \\
\text { worldwide }\end{array}$ & $\begin{array}{l}\text { Official reports [36], } \\
\text { media reports (MedISys } \\
\text { alert) }\end{array}$ & $\begin{array}{l}\text { At the end of the } 2010 \text { World Cup, } 413 \\
\text { cases of WPV } 1 \text { had been reported in } \\
2010 \text { in Tajikistan ( } 76 \% \text { of the cases } \\
\text { worldwide). Local media reported } \\
\text { cases in Russia. }\end{array}$ & $\begin{array}{l}\text { The monitoring of poliomyelitis worldwide is part } \\
\text { of ECDC routine epidemic intelligence activities. } \\
\text { Considering the risk of appearance of the disease } \\
\text { in the EU, special epidemic intelligence attention } \\
\text { was dedicated to Tajikistan and Russia. No } \\
\text { relevance for the } 2010 \text { World Cup. }\end{array}$ \\
\hline $\begin{array}{l}\text { Influenza, } \\
\text { worldwide } \\
\text { (excluding } \\
\text { South Africa) }\end{array}$ & $\begin{array}{l}\text { WHO [31], personal } \\
\text { communication } \\
\text { from national health } \\
\text { authorities, media reports } \\
\text { (MedISys alert) }\end{array}$ & $\begin{array}{l}\text { Special emphasis was dedicated } \\
\text { to southern hemisphere activity. } \\
\text { During the period covered, most } \\
\text { countries had sporadic to low activity. } \\
\text { Circulation of influenza } A\left(\mathrm{H}_{3} \mathrm{~N}_{2}\right) \\
\text { and } \mathrm{A}\left(\mathrm{H}_{1} \mathrm{~N}_{1}\right) \text { viruses was described } \\
\text { in several areas of Central and } \\
\text { South America; limited activity was } \\
\text { described in Africa; in Asia, the main } \\
\text { circulation was reported in Malaysia, } \\
\text { Singapore and south-west India. }\end{array}$ & $\begin{array}{l}\text { In addition to ECDC routine monitoring, we selected } \\
\text { three countries as sentinel sites (New Zealand, } \\
\text { Singapore and Australia) with well-established } \\
\text { surveillance systems in order to closely monitor the } \\
\text { activity in the southern hemisphere. No relevance } \\
\text { for the } 2010 \text { World Cup. }\end{array}$ \\
\hline $\begin{array}{l}\text { Dengue, } \\
\text { worldwide }\end{array}$ & $\begin{array}{l}\text { Personal communication } \\
\text { from national health } \\
\text { authorities, media reports } \\
\text { (MediSys alert) }\end{array}$ & $\begin{array}{l}\text { Central and South American countries } \\
\text { were particularly affected, but no } \\
\text { unusual situation was reported. }\end{array}$ & $\begin{array}{l}\text { The monitoring of relevant dengue outbreaks } \\
\text { worldwide is part of ECDC routine epidemic } \\
\text { intelligence activities, considering the risk of } \\
\text { locally acquired cases in Europe. No relevance for } \\
\text { the } 2010 \text { World Cup. }\end{array}$ \\
\hline $\begin{array}{l}\text { Plague, } \\
\text { Myanmar }\end{array}$ & $\begin{array}{l}\text { Media reports (MedISys } \\
\text { alert) }\end{array}$ & $\begin{array}{l}\text { Several media reports about an } \\
\text { outbreak in Rangoon (Myanmar). }\end{array}$ & $\begin{array}{l}\text { ECDC validated the information through WHO. The } \\
\text { event was considered very unusual but without } \\
\text { implications for the } 2010 \text { World Cup. }\end{array}$ \\
\hline Plague, Syria & $\begin{array}{l}\text { ProMed [37], media } \\
\text { reports (MedlSys alert) }\end{array}$ & $\begin{array}{l}\text { Several media reports about cases } \\
\text { confirmed among military personnel } \\
\text { in Syria, where no case has been } \\
\text { described in the previous } 40 \text { years. }\end{array}$ & $\begin{array}{l}\text { ECDC validated the information through its } \\
\text { epidemic intelligence network. The source } \\
\text { was found to be unreliable and no cases were } \\
\text { confirmed by authorities. No relevance for the } 2010 \\
\text { World Cup. }\end{array}$ \\
\hline
\end{tabular}

ECDC: European Centre for Disease Prevention and Control; EU: European Union; FIFA: Fédération Internationale de Football Association; WHO: World Health Organization; WPV1: wild poliovirus 1.

The enhanced surveillance period was from 7 June to 16 July 2010.

MediSys, developed at the Joint Research Centre of the European Commission, is an Internet-based system that continuously monitors specialist medical sites and news sites to rapidly identify potential threats to public health.

participants from all over the world, public health may benefit from specific surveillance activities directed at infectious diseases and other health risks during the event. ECDC carried out enhanced event-based surveillance for the 2010 World Cup to maximise timely detection and risk assessment communication to EU stakeholders concerning relevant infectious diseases circulating among participants at the tournament or occurring globally. Timeliness was achieved by using both official and non-official information sources. The gathering of information was made effective through a daily process making use of a tailored web-based screening tool (MedISys).
There are limitations on the use of public sources and web-screening tools for event-based surveillance. The detection of public health events from official sources is possible but is dependent on the information being made available regularly and in a timely manner in the public domain, e.g. as regional or national surveillance reports (as undertaken by the NICD during the World Cup). When information is gathered from non-official sources, such as the media, the reporting of isolated cases or outbreaks relies solely on what captures the interest of reporters/journalists, e.g. a disease that occurs in a high-profile individual or a public health rumour with political or economic implications. Thus it is important to take into consideration that reports of public health events detected through web-aggregators 
using media sources can only be a complement to what is detected through mandatory event-based surveillance, such as the International Health Regulations (IHR) or the EU's Early Warning and Response System (EWRS), together with traditional indicator-based surveillance used in national and international disease surveillance systems. Nonetheless, the advantage of reports from non-official sources, if corroborated after validation from official sources, is that they can provide a timely indication of a possible public health threat or can assist in directing corrective public health communication.

Our gathered and validated information was shared with all relevant decision-makers in EU Member States as well as the international community through our daily bulletins during the entire enhanced surveillance period. The enhanced surveillance by ECDC offered a rumour-control function as well, exemplified by a supposed plague outbreak in Syria (Table 4), which was reported by the media but quickly discarded after examination of information from the ECDC El network.

There were no international or local events posing serious risk to the World Cup during the surveillance period apart from the ongoing local measles outbreak, which also affected visitors. The subsequent detection of measles cases in several countries after the World Cup, with secondary transmission in some places, clearly demonstrated the risk of exportation of vaccine-preventable diseases through visitors returning from a hosting country. This pattern was previously reported following a MG when measles occurred among residents of British Columbia, Canada, after the Winter Olympic Games in Vancouver in 2010, leading to the first major outbreak of the disease in the province since 1997 [28].

Regarding the other reported diseases, the majority of cases were community-based or local sporadic cases. Influenza activity was low to moderate and followed the seasonal trends in the country. There was an expected seasonal activity of meningococcal disease, with sporadic cases in the local population [29].

We also monitored media reports, later confirmed, about individuals in Pretoria being in possession of radioactive materials (caesium-137) and trying to sell it for the production of a dirty bomb during the tournament, but this was not considered a risk for the event [30].

Although no major relevant public health events related to the World Cup occurred, ECDC considers the investment of technical preparations and workforce time used in the enhanced surveillance during the World Cup to be justified. The targeted activities carried out by the ECDC El team during the World Cup allowed the accurate and timely identification and analysis of public health risks during the event for the entire EU/EEA community, thus saving resources for the individual EU
Member States. Additions to MedISys continue to be used beyond the specific filters of the 2010 World Cup and contacts and collaboration with public health partners are a long-term legacy for El activities.

Furthermore, ECDC's enhanced surveillance activities provide an additional safety net to that of other $\mathrm{EI}$ actors at an international level, e.g. the Global Public Health Intelligence Network (GPHIN), HealthMap, PULS (an automated news media monitoring platform) and WHO. Redundancy among El systems provides an added safety system for global public health security.

\section{Conclusions}

The enhanced El activities by ECDC during the 2010 World Cup, together with the close collaboration of the NICD and WHO, allowed the detection, assessment and communication of relevant health threats potentially affecting EU Member States. Tailored El surveillance for large international MGs should continue as a core function for ECDC. From each MG experience, ECDC learns how to improve its El procedures, provide a sound basis for how to best support EU Member States and hosting countries worldwide and broaden the existing knowledge base for future MGs. The added value of the ECDC El support for the national authorities in the hosting countries can vary considerably depending on existing surveillance systems and national surveillance capacities. It is important to define which tools to use for gathering information, to identify specific filtering criteria in collaboration with the authorities in the hosting countries and to clarify the information flow among the public health partners.

\section{Acknowledgements}

We thank the whole ECDC Epidemic Intelligence group for the work done during the event; the National Institute for Communicable Diseases, South Africa, for their strong participation in our epidemic intelligence process and for the availability for daily contacts and collaboration in risk assessment analysis.

Conflict of interest

None declared.

\section{Authors' contributions}

$J M$ participated in the design, coordination and analysis of this study and drafted the manuscript. ES, LHP, AL, ED and DC helped in the draft of the manuscript and provided relevant feedback on discussion and conclusions; BK provided relevant input on results in particular, JL contributed to the methodology part; LB provided input and feedback on the manuscript, contributing mainly to the perspective from the host country authorities side.

\section{References}

1. FIFA. 2010 FIFA World Cup South Africa. Zurich: FIFA. [Accessed 2 Jun 2010]. Available from: http://www.fifa.com/worldcup/ archive/southafrica2010/index.htm 
2. South African Tourism. Impact of 2010 FIFA World Cup. Johannesburg: South African Tourism; 2010. Available from: https://tkp.tourism.gov.za/documents/impact $\% 200 \% \% 20$ 2010\%20fifa\%20world\%20cup.pdf

3. World Health Organization (WHO). Communicable disease alert and response for mass gatherings: key considerations, June 2008. Geneva: WHO; 2008.

4. European Centre for Disease Prevention and Control (ECDC). Epidemic Intelligence tutorial. Stockholm: ECDC. [Accessed 2 May 2011]. Available from: http://external.ecdc.europa.eu/ El Tutorial/course.htm

5. Paquet C, Coulombier D, Kaiser R, Ciotti M. Epidemic intelligence: a new framework for strengthening disease surveillance in Europe. Euro Surveill. 2006;11(12):pii=665.

6. Linge JP, Steinberger R, Weber TP, Yangarber R, van der Goot E, Al Khudhairy $\mathrm{DH}$, et al. Internet surveillance systems for early alerting of health threats. Euro Surveill. 2009;14(13):pii=19162.

7. Mantero J, Belyaeva E, Linge JP. How to maximise eventbased surveillance web-systems: the example of ECDC JRC collaboration to improve the performance of MedISys. Luxembourg: Publications Office of the European Union; 2011. Available from: http://publications.jrc.ec.europa.eu/ repository/bitstream/111111111/16206/1/lb-na-24763-en-c.pdf

8. Barboza P, Vaillant L, Mawudeku A, Nelson NP, Hartley DM, Madoff LC, et al. Evaluation of epidemic intelligence systems integrated in the early alerting and reporting project for the detection of $\mathrm{A} / \mathrm{H}_{5} \mathrm{~N}_{1}$ influenza events. PLoS One. 2013;8(3):e57252.

http://dx.doi.org/10.1371/journal.pone.0057252

9. Regulation (EC) No 851/2004 of the European Parliament and of the Council of 21 april 2004 establishing a European centre for disease prevention and control. Official Journal of the European Union. Luxembourg: Publications Office of the European Union. 30.4.2004: L 142. Available from: http://www. ecdc.europa.eu/en/aboutus/key\%20documents/0404_kd_ regulation_establishing_ecdc.pdf

10. National Institute for Communicable Diseases (NICD), South Africa. Communicable diseases communiqué. May 2010:9(5). Johannesburg: NCID; 2010. Available from: http://www.nicd. ac.za/assets/files/NICDCommMay10Volo9_05.pdf

11. National Institute for Communicable Diseases (NICD), South Africa. Communicable diseases communiqué. Jun 2010:9(6). Johannesburg: NCID; 2010. Available from: http://www.nicd. ac.za/assets/files/NICDCommJune10Volo9_06.pdf

12. National Institute for Communicable Diseases (NICD), South Africa. Communicable diseases communiqué. Jul 2010:9(7). Johannesburg: NCID; 2010. Available from: http://www.nicd. ac.za/assets/files/NICDCommJuly10Volo9_07.pdf

13. Blumberg L, de Frey A, Frean J, Mendelson M. The 2010 FIFA World Cup: communicable disease risks and advice for visitors to South Africa. J Travel Med. 2010;17(3):150-2. http://dx.doi.org/10.1111/j.1708-8305.2010.00413.x

14. Robert Koch Institute (RKI). Fallbericht. Aus Südafrika importierte Infektion mit Rifttal-Fieber-Virus. [Case report. Imported Rift Valley fever virus from South Africa]. Epidemiologisches Bulletin. 3 May 2010;17:158-9. Available from: http://www.rki.de/DE/Content/Infekt/EpidBull/ Archiv/2010/Ausgaben/17_10.pdf;jsessionid=044A188B78A87 7A25E2CE82B42D48711.2_cid298?_blob=publicationFile

15. Robert Koch Institute (RKI). Aktuelle Information zum Fallbericht: Fieberhafte Erkrankung nach Südafrikaaufenthal. [Update of case report: a case of febrile illness returning from South Africa]. Epidemiologisches Bulletin. 17 May 2010;19:176. Available from: http://edoc.rki.de/documents/rki_fv/ reaN2E7gpPCX/PDF/24fprNAosjp6F2.pdf

16. Goal.com. World Cup opera singer Siphiwo Ntshebe dies from meningitis. Goal.com; 26 May 2010. Available from: http:// www.goal.com/en/news/89/africa/2010/05/26/1944414/ world-cup-opera-singer-siphiwo-ntshebe-dies-from-meningitis

17. ProMED-mail. Measles - Australia ex South Africa. Archive Number: 20100709.2299. 9 Jul 2010. Available from: http:// www.promedmail.org/direct.php?id=20100709.2299

18. ProMED-mail. Measles - Australia (06): Queensland ex South Africa. Archive Number: 20100914.3329.14 Aug 2010. Available from: http://www.promedmail.org/direct. php?id=20100914.3329

19. Ministry of Health, Argentina. Casos confirmados de sarampión. [Confirmed measles cases]. Alertas Epidemiológicos anteriores No. 8. [Latest epidemiological alerts No. 8]. Buenos Aires: Ministry of Health; 30 Sep 2010. [Accessed 2 May 2011]. Spanish. Available from: http://www. msal.gov.ar/images/stories/alertas_epidemiologia/2010/ alerta_8_sarampion_30-9-2010.pdf

20. infobae. Casos de sarampión en Brasil y Argentina alertan a Uruguay. [Uruguy is on alert due to measles cases in Brazil and Argentina]. Buenos Aires: infobae; 23 Aug 2010. Spanish.
Available from: http://www.infobae.com/2010/08/23/1007090casos-sarampion-brasil-y-argentina-alertan-uruguay

21. La Nacion Digital. Sarampión: detectan dos casos en Brasil. [ Measles: two cases detected in Brazill. Buenos Aires: La Nacion; 21 Aug 2010. Spanish. Available from: http://www.lanacion.com. ar/1296559-sarampion-detectan-dos-casos-en-brasil

22. Yonhap News Agency. Korean dancer dies of malaria after trip to Africa. Seoul: Yonhap News Agency; 23 Jun 2010. Available from: http://english.yonhapnews.co.kr/news/2010/06/23/0200 000000 AEN20100623011100315. HTML? source $=$ rsS

23. ProMED-mail. Rabies - South Africa (02): (Gauteng) Canine, human suspected. Archive Number: 20100928.3519. 28 September 2010. Available from: http://www.promedmail.org/ direct.php?id=540634

24. Malerczyk C, Nel LH, Gniel D, Blumberg L. Rabies in South Africa and the FIFA Soccer World Cup: travelers' awareness for an endemic but neglected disease. Hum Vaccin. 2010;6(5):3859. http://dx.doi.org/10.4161/hv.6.5.11713

25. National Institute for Communicable Diseases (NICD), South Africa. Rabies confirmed In child In Johannesburg Metropolitan. Johannesburg: NCID: 27 Sep 2010. Available from: http://www.nicd.ac.za/?page=alerts \&id $=5 \&$ rid $=41$

26. IOL sport. Food poisoning hit Fifa workers. South Africa: IOL sport; 18 Jun 2010. Available from: http://www.iol.co.za/sport/ food-poisoning-hit-fifa-workers-1.619038

27. dalje.com. 90 World Cup volunteers suffer food poisoning at stadium. Croatia: dalje.com; 18 Jun 2010. Available from: http://dalje.com/en-world/90-world-cup-volunteers-sufferfood-poisoning-at-stadium/310535

28. Naus M, Sahni V, Gustafson R, Brodkin E, Parker R, Fyfe M, et al. An outbreak of measles in British Columbia, Canada: an unwelcome consequence of the 2010 Winter Olympics. 48th annual meeting of the Infectious Diseases Society of America 21-24 October 2010; Vancouver, British Columbia, Canada. Abstract available from: https://idsa.confex.com/idsa/2010/ webprogram/Paper4104.html

29. Blumberg L. 2010 FIFA soccer World Cup, South Africa: communicable disease risks and surveillance. Communicable Diseases Surveillance Bulletin. November 2010;8(4):634. Available from: http://www.nicd.ac.za/assets/files/ Bulletin\%20November\%202010(1).pdf

30. IOL news. Four bust in 'dirty bomb' sale sting. South Africa: IOL news; 10 Jul 2010. Available from: http://www.iol.co.za/news/ south-africa/four-bust-in-dirty-bomb-sale-sting-1.489373\#. UTYoaKKEoWk

31. World Health Organization (WHO). Situation updates pandemic $\left(\mathrm{H}_{1} \mathrm{~N}_{1}\right)$ 2009. Geneva: WHO. [Accessed Jul 2010]. Available from: http://www.who.int/csr/disease/swineflu/ updates/en/

32. Ethnos. [Measles ... introduction of the epidemic from Bulgaria]. Greece: Ethnos; 6 Jul 2010. Greek. Available from: http://www.ethnos.gr/article.asp?catid=22768\& subid =2\&pub id $=19092956$

33. Il Resto del Carlino. Carpigiano torna dal Brasile ammalato di dengue. Scatta la disinfestazione. [A returning visitor from Brazil falls ill with dengue in Carpi. Need for vector control]. Modena: Il Resto del Carlino. 15 Jun 2010. Italian. Available from: http://www.ilrestodelcarlino.it/modena/ cronaca/2010/06/15/345592-carpi_caso_dengue.shtml

34. Health Protection Scotland (HPS). Anthrax outbreak information. Glasgow: HPS; 2010. [Accessed Jul 2010]. Available from: http://www.hps.scot.nhs.uk/giz/ anthraxoutbreakdecember2009december2010.aspx

35. National Center of Infectious and Parasitic Diseases (NICPD), Bulgaria. [Measles in Bulgaria]. Sofia: NICPD; 2010. [Accessed Jul 2010]. Bulgarian. Available from: http://www.ncipd. org/?news=disease\# 28

36. Global Polio Eradication Initiative. Polio worldwide. Geneva: Global Polio Eradication Initiative; 2010. [Accessed Jul 2010]. Available from: http://www.polioeradication.org/ Dataandmonitoring/Poliothisweek.aspx

37. ProMED-mail. Plague - Syria: military, suspected, request for information. Archive Number: 20100704.2222. 4 July 2010. Available from: http://www.promedmail.org/direct. php?id=458779 